\title{
Global Markets and Time-Based Competition
}

\author{
Elisa Rancati*
}

\begin{abstract}
Time becomes the benchmark that defines a company's strategic behaviour, extensively revamping the entire company by reinterpreting the time dimension in a different, extremely dynamic context.

Marketing activities always presuppose time-based competition. From a marketing perspective, oriented to analysis of the competition, time-based competition can be defined as a strategy based on immediate response to the customer's needs.

In the competitive conditions of over-supply, the time dimension, as it is indicated by time-based competition, is of great significance for the measurements and characteristics of performance measurement systems.
\end{abstract}

Keywords: Global Markets; Time-Based Competition; Time Compression; Time-to-Market; Global Competition

\section{Global Markets, Over-Supply and Time-Based Competition}

The most characteristic features of today's competitive scenario are: globalisation; changing space relations of competition ${ }^{1}$; a dynamic conception of competition; a growing complexity of products and processes; hypercompetition; accelerating technological innovation; rapid imitation of innovations; shorter lifecycles of products and technologies.

As we can see, all the factors listed refer explicitly to one of the thresholds of globalisation ${ }^{2}$ : the temporal dimension. In order to resist the thrust of global competition, companies must be able to cross the threshold of globalisation where the temporal horizon is concerned, because they are fighting a daily 'battle against time'.

Against this background, increasingly fierce competition tension at a global level poses the problem of interpreting and managing a timeframe that is increasingly imposed by the market. Compared to the typical competitive conditions on proximity

* Assistant Professor of Management, University of Milan- Bicocca (elisa.rancati@unimib.it)

Rancati Elisa, Global Markets and Time-Based Competition, Symphonya. Emerging Issues in Management (symphonya.unimib.it), n. 2, 2005, pp. 58-69 
markets, where supply is generally scarce, it is no longer the market that depends on the company and its internal timing structures, but the other way round.

What is more, on global, over-supplied markets, time becomes the synchronising element of periodical product change: an extensive range of models is introduced on the market, in various price/quality ranges that change according to timing intervals dictated by leading companies on the global market, triggering phenomena of programmed obsolescence. Periodical model changes lead to an evolution of standardisation, going from a standard product to a differentiated product ${ }^{3}$.

In corporate management, as global markets develop, new models are introduced for the planning and realisation of products that use the same components in different manufacturing processes (modularity of production ${ }^{4}$ ), thus achieving important economies of scale.

The efficient interpretation of time that was typical of Ford's philosophy and of proximity markets, in other words tied to cost saving and to the achievement of economies of scale thanks to modular production, is enriched by a growing attention to the values related to the specific needs of the market.

The orientation to demand and marketing typical of proximity markets and international markets is unable to resist the thrust of the multiplication of supply. The result is to disseminate a new managerial perspective of global over-supplied markets, based on analysis of the competition. Beating competitors, all of whom strive to meet temporary needs, becomes a strategic imperative for companies operating in the new competitive contexts, both present and future, of the global markets.

By adopting a competitor orientation to deal with the over-supply, but above all to increase the quantity of demand, companies exploit resources of environments dominated by product intangible assets, like the time factor ${ }^{5}$, designed to drive the competition in entire sectors towards instable new competitive structures, based on intangible factors that can make it possible to seek a lasting competitive advantage ${ }^{6}$.

Time becomes the benchmark that defines a company's strategic behaviour, extensively revamping the entire company by reinterpreting the time dimension in a different, extremely dynamic context ${ }^{7}$.

Global companies increase their performance with just-in-time and delocalisation and first of all with a better management of incoming and outgoing information flows ${ }^{8}$. The action-reaction cycle may be defined as 'the sum of measures that constitute a company's competitive action and the market's subsequent reaction; a reaction that triggers a new cycle originating with the counter-reaction of the company in question',

Considering a single company unit from inside, we can identify not only the action and reaction, but also another component of the cycle: the feedback and feed-forward mechanisms that are closely connected to the collection, selection, processing and analysis of the retro-action information ${ }^{10}$.

Feedback mechanisms are the returning information about the result of a process, which can be used to rectify the input of a process, or the process itself, in order to maintain the desired performance levels or to control a system's stability ${ }^{11}$. Feedback information flows are indispensable because they allow managers to perform and update SWOT Analysis based on changes in competitive dynamics 
and in internal skills, and they represent the spinal cord of systems to measure and control a company's performance ${ }^{12}$.

The increased dynamism expressed by the economic environment may in part be attributed to the increase in the quality and quantity of information available to companies, thanks to rapidly evolving information technologies. Richer, faster communications and information make feedback mechanisms more immediate, keeping companies informed of environmental events taking place some distance away (information regarding markets, the competition, and the competitive behaviour of other companies) and triggering mechanisms of imitation and therefore of change.

Feed-forward flows are defined as the retro-action process that emerges when a specific action is not yet concluded, and presupposes incoming and outgoing information flows that allow control and amendment action during the course of intervention ${ }^{13}$.

On global markets, the development and spread of information technologies in companies, the speed of the spread and imitation of innovation and the demand for products with ever-shorter delivery times ${ }^{14}$, have induced companies to integrate ${ }^{15}$ in a network of instable short-term relations with corporate structure that are compact and integrated, but flexible in relation to their boundaries and external connections. The changes taking place imply the need to speed the action and reaction cycles, reducing the time necessary to realise the entire development cycle of the market policies of a company that is part of a network.

Time is therefore considered as the company's main tool to obtain sustainable and defendable competitive advantages, becoming 'a central element of the reorganisation of all company processes, and of the review of the logics and methods that manage the relationship between company and market', and the main tool to renew the planning of corporate communication ${ }^{16}$, extended to all communication activities (commercial, corporate and organisational), to the information flows (external, internal, co-makers), and to the various forms of corporate information (personal, impersonal, but above all electronic).

\section{Global Markets, Time Compression, Time Value and Time Duration}

Speeding up action and reaction cycles forces companies to carefully examine corporate processes with an eye to time compression.

With time compression, the focus is on reducing the amount of time consumed by corporate processes: the conversion of input to output that takes place in corporate processes follows specific stages, but in a very compressed timeframe.

To compress time it is necessary to eliminate waste (i.e. any stages and operations that do not generate a specific increase in value in terms of output) refocusing the sequence of activities in order to minimise time consumption in each process that makes up the company's chain of value, from the design stages to the operative stages.

Going on to a strategic analysis of time compression in the management of a global company, mass dismissals and the introduction of flexible manufacturing machinery are identified as targets to achieve time reduction inside the company. 
The analysis shifts from the compression of corporate processing times, due to an increasingly incisive acceleration of action and reaction cycles, towards efforts to optimise the ways the time dimension is used in the company's decision-making processes.

Like time compression, time value expresses a strictly competitive value of the time factor, highlighting in particular the way time is used in the corporate planning process. The focus of the analysis shifts from the efficient management of operating processes that is typical of time compression, to the planning of the market policy development cycle.

This evaluation of the time factor can be qualified in the following managerial steps: the selection, analysis and interpretation of crucial information; the choice and planning of intervention; the choice of the correct action time, and network timing, in an unlimited 'megaspace' with incoming and outgoing information flows in which control of the various activities may be guaranteed by intermediate forms of coordination (global networks).

Thanks to the acceleration of action and reaction cycles, contacts are activated inside the company, between companies and with the market, minimising the cost, but above all the time necessary to collect, analyse and distribute the information flows.

The definition of network timing can be separated from the 'time compression' dimension, but it is closely tied to the situation on the market (such as over-supply) or to the implementation of certain selling policies ${ }^{17}$.

In strategic terms, the optimal choice of action time could be represented by application methods like the accumulation of technological knowledge, the anticipated planning of new products independent of the timing of the market launch, and the creation of private labels ${ }^{18}$ in retail companies that may be introduced on the market as a consequence of emerging new opportunities/threats. In addition to their aptitude to represent an essential element that can differentiate supply strengthen the image, marketing brands qualify supply in a timely and distinctive way, not directly imitable by competitors in the short term, reducing price-based competition and reinforcing time-based competition. The growing importance of private labels lies in the ability to transfer all the innovation costs from the retailer to the manufacturer, rapidly increasing the development rate of new product categories and lines, and reducing time to market.

Tesco, the largest British supermarket chain and world's third largest retail chain, is one of the large organised retail chains most projected towards innovative forms of private labels, in the food and non-food sectors. Every year, Tesco launches over 2,000 new products on the market with its own trademark.

Tesco leads the organic products market, with over 1200 lines, as well as the market of products for people with food allergies/intolerance.

In collaboration with Royal Bank of Scotland, Tesco offers its customers a wide range of financial products. The 'Tesco Personal Finance' (TPF) programme, launched in 1997 with the giant Scottish bank, now offers mortgages, insurance policies, credit cards, loans, bonds and savings accounts. 
Tesco is Britain's largest independent supplier of petrol and diesel vehicle fuel. It controls 325 distributors, located near to its retail stores and covers $12.5 \%$ of the British market. Tesco also provides over-the-counter pharmaceutical products and telecommunications: the Tesco range includes telephone, internet and broadband services. ${ }^{19}$

This approach starts from an analysis of the close link between the time dimension and the company's competitive advantage: the speed of response to the market is considered as an important strategic factor for companies.

Global over-supplied markets, where the competitive intensity ${ }^{20}$ is very high, oblige companies to reinterpret time structures ${ }^{21}$ : "when formulating strategy, it is indispensable to decide the main strategic challenges and to push for change as rapidly as possible, piloting the course of action between too much too soon and too little too late ${ }^{, 22}$.

When competitive behaviour analysis is combined with the growing importance of the time factor in corporate processes and in the company supply system, competitor orientation must be examined as a priority by the temporal dimension. This disseminates a strategic competitor orientation based on the time that influences the action-reaction process in relation to competitors, with the goal of increasing the dynamics of demand ${ }^{23}$.

To deal with these dynamics, techniques such as demand segmentation used when demand and supply are balanced, must be reinterpreted generating demand bubbles to manage the instability and complexity of over-supplied markets ${ }^{24}$.

Demand bubbles refer to an interpretation of time ${ }^{25}$ known as 'time duration', in other words the duration of the demand bubble ${ }^{26}$.

From the embryonic stage, during the planning of the bubble, in the light of a precise analysis of demand, the company must envisage not only the methods to implement supply but also the timing interval necessary to resolve the supply.

When the bubble appears, time compression must allow the company to group together purchasers who are potentially interested in the company's specific proposal. The more time is compressed, the greater the strategic significance associated with it: a rapid aggregation of purchasers will enable the company to promptly cover the investment in financial terms. The demand bubble will remain active for a short period of time (for example a few months or one or two weeks at the most).

The lack of repetition in clients' purchasing behaviour and therefore the temporary nature of supply proposals, translate into the absence of the condition of stability which characterises the bubble regardless of the segment.

Time-based competition is a potentially revolutionary opportunity for the company; its intrinsic potential may be higher or lower depending on the company's propensity to use it to develop opportunities for business with clients, the market and partners.

Marketing activities always presuppose time-based competition. From a marketing perspective, oriented to analysis of the competition, 'time-based competition can be defined as a strategy based on immediate response to the customer's needs and the rapid introduction of new products, together with competitive costs and quality ${ }^{27}$. 
In conditions of over-supply and hypercompetition, companies cannot disregard the need to understand the nature of the competition and competitive action put in place by the companies, because of the evolution of information technologies, the rapid transmission of information flows, and immediate imitation of innovation. All these are phenomena in which time changes the basic rules for the creation and maintenance of the competitive advantage (Table 1).

Table 1: Time-Based Competition in Conditions of Over-Supply

\begin{tabular}{|l|}
\hline \multicolumn{1}{c|}{ Time-Based Competition } \\
\hline Intangible-based competition \\
Acceleration of action and reaction cycles \\
Instable/dynamic markets \\
Continuous, dynamic innovation \\
Cooperative competition \\
\hline
\end{tabular}

\section{Global Markets, Performance Metrics and Time-Based Competition}

In the competitive conditions typical of over-supplied global markets, the time dimension, as it is indicated by time-based competition, is of great significance for the measurements and characteristics of performance measurement systems.

The major internal time measurements are process and set-up times, for example, for which specific standard times exist; where external time is concerned, the most significant measurements are time-to-market, order completion time and lead times for provisioning and manufacturing.

Over-supply underlines the crucial importance of choice time, maximising the opportunities and profitability of the physical exposure (on the shelves) and virtual exposure (virtual windows) of specific products.

The performance ratings used most extensively in the shelf policies of manufacturing companies favour non-cost performance, which is determined in quantitative non-monetary terms, expressed in absolute values or in percentages, closely linked to the time factor.

When the timeframe of a performance is critical, i.e. product sell-out from a point of sale, the performance indicator used by over-supplied companies is the product rotation index.

Manufacturers and retailers generally compete with non-antagonistic policies, to the creation of temporary offers in a short period of time (time compression) to meet particular expectations of instable aggregations of end consumers (demand bubbles) with the common goal of 'creating a stimulating shelf" ${ }^{28}$.

Measurement systems that are based on the determination of inventory sizes, contribution margins or market share begin to show their inadequacy to meet the need for governance of a company operating in conditions of over-supply that become increasingly complex and dynamic. This occurs because we are gradually moving away from scarcity economies and controlled competition markets, in 
which demand and supply are very unbalanced or in a dynamic balance, which guarantee the full efficiency of the orientation to costs and sales.

There is another implication of the adoption of time-based performance indicators: companies that compete in contexts that are not over-supplied, achieve their goal of obtaining a minimum of flexibility by fragmenting the processes ${ }^{29}$; warehouses are an expedient that makes it possible to obtain manufacturing flexibility in a context of rigid machines. Companies operating in the megaspace without physical boundaries of the global, over-supplied markets, because of the extreme dynamism that distinguishes them, determine inventory sizes only taking into account the technical function of the inventory in question, in other words the speed with which manufacturing and consumption processes are fed. Inventories are kept to a minimum (when they are not actually abolished, as in the case of a dot.com) to enable the company to save on inventory costs (financial charges, storage costs, insurance inventories, possible maintenance). Inventories of raw materials must be kept on hand in the necessary quality and quantity to ensure that there are no down times in manufacturing because of a lack of raw materials. Cost-based performance measurements (by value) that quantify the monetary value of inventories are abandoned ${ }^{30}$, in favour of indices based on the speed with which raw materials leave the warehouse, such as the inventory rotation index.

Time-based performance indicators of over-supplied global companies can be traced back as something that "can be qualified by the incessant dynamism of the economy, by short, medium and long-term variations, by favourable or negative economic situations, by lasting situations of relative stability, or by rapid and profound changes related to technological, social or political factors in which the pertinence of income items to specific operating years may be reasonably determined at least to a certain extent, with changing criteria according to the changing trend and different perspectives of economic time" 31 .

Time-based performance indicators must not only represent the event in the best possible way, but they should also reveal the significant problems for corporate management in order to identify the most opportune moment to propose a given action (time value), to influence and value a possible overlap between strategic choices (analysis dimension, with a medium-long term outlook) and operational choices (action dimension, with a short-term outlook) ${ }^{32}$.

A time-based performance measurement system is designed and developed to identify information flows with very fast action-reaction times, to be activated with the goal of making it possible to enable components of the organisation to learn from and align their behaviour (feedback and feedforward).

\section{Bibliography}

Amigoni F. (ed.), Sistemi di controllo e misurazione delle performance, Egea, Milan, 2001.

Ansoff H.I., La strategia d'impresa, Franco Angeli, Milan, 1974.

Askenazy P., Thesmar D., Thoenig M., Time Based Competition And Innovation, ENSAE, New York, 2003.

Brondoni S.M., Ouverture de 'Global Markets \& Marketing Research', Symphonya. Emerging Issues in Management (symphonya.unimib.it), n. 1, 2003. 
http://dx.doi.org/10.4468/2003.1.01ouverture

Brondoni S.M., Time compression and time value as a competitive strategy, Morello G. (ed.), Time and management, Proceedings of the International Conference, Palermo 6-8 aprile 2000, ISIDA, Palermo, 2001.

Brondoni S.M., Lambin J.J., Ouverture de 'Market-Driven Management', Symphonya. Emerging Issues in Management (symphonya.unimib.it), n. 1, 2000-2001. http://dx.doi.org/10.4468/2001.1.01ouverture

Brondoni S.M., Con la rete costi più bassi e più diffusione. Aumenteranno le edizioni fatte su misura, Il Sole 24 Ore, 10 april 2000.

Brondoni S.M., E-Economy \& gestione competitiva del tempo, Il Sole 24 Ore, 8 maggio 2000.

Brondoni S.M., Le due regole del mercato. Vince per primo chi capisce le esigenze dei consumatori, Il Sole 24 Ore, 3 maggio 1999.

Brondoni S.M., Comunicazione integrata d'impresa e 'nuove sfide' competitive, R. Filippini, G. Pagliarani, G. Petroni (eds), Progettare e gestire l'impresa innovativa. I nuovi percorsi per affrontare la complessità degli anni Novanta, ETAS Libri, Milan, 1992.

Brondoni S.M., Giulivi A., Competizione time-based e nuova progettualità della comunicazione aziendale, Sinergie, n. 9, 1993.

Claesson C., Mental Overlevnadsteknik, Carlssons Bokforlag, Stockholm, 1994.

Corniani M., Demand Bubble Management, Symphonya. Emerging Issues in Management (symphonya.unimib.it), n. 1, 2002. http://dx.doi.org/10.4468/2002.1.08corniani

de Woot P., The Challenges of Economic Globalisation. Business, Competition and Society, Symphonya. Emerging Issues in Management (symphonya.unimib.it), n. 2, 2002.

http://dx.doi.org/10.4468/2002.2.03dewoot

Gnecchi F., Le private label nell'economia d'impresa, Giappichelli, Turin, 2002.

Guatri L., Freedomland. Un'esperienza sul valore conseguente ad uno start-up IPO, Egea, Milan, 2002.

Hum S., Sim H., Time-based Competition: Literature Review And Implications For Modelling, in International Journal of Operations and Production Management, vol. 16, n. 1, 1996.

http://dx.doi.org/10.1108/01443579610106373

Johnson H.T., Relevance Regained. From Top-Down Control To Bottom-Up Empowerment, The Free Press, New York, 1992.

Lambin J.J., Marketing strategico e operativo, Mc Graw Hill, Milan, 2000.

Martinelli A.F., From Cornering to Virtual Cornering, Symphonya. Emerging Issues in Management (symphonya.unimib.it), n. 1, 2002. http://dx.doi.org/10.4468/2002.1.07martinelli

Massaroni E., Forme, caratteri e divenire sistemico dei rapporti di fornitura, Golinelli G. M., L'approccio sistemico al governo dell'impresa. Valorizzazione delle capacità, rapporti intersistemici e rischio nell'azione di governo, volume terzo, CEDAM, Padua, 2002.

Normann R., Ridisegnare l'impresa, ETAS Libri, Milan, 2002.

Onida P., Economia d'azienda, Utet, Turin, 1970.

Onida P., La logica e il sistema delle rilevazioni quantitative d'azienda, Giuffrè, Milan, 1970.

Onida P., Natura e limiti della politica di bilancio, in Rivista dei Dottori Commercialisti, novembredicembre, 1974. 
Panati G., Golinelli G. M., Tecnica economica industriale e commerciale. Imprese, strategia e management, volume I-II, La Nuova Italia Scientifica, Rome, 1991.

Paniccia P., Dinamiche temporali e cognitive nell'approccio sistemico al governo dell'impresa, CEDAM, Padua, 2002.

Paniccia P., Il tempo nel governo dell'impresa industriale, Giappichelli Editore, Turin, 1999.

Pivato G., Le scorte d'esercizio nelle imprese industriali e mercantili, Cavalleri, Como, 1942.

Rullani E., Produzione snella e post-fordismo: alla ricerca di un paradigma emergente, Economia $e$ politica industriale, n. 84, 1994.

Salvioni D.M., Il sistema di controllo della gestione, Giappichelli Editore, Turin, 1997.

Sloan A. P. Jr., La mia General Motors, Il Sole 24 Ore Libri, Milan, 1991.

Stalk G. Jr., Il tempo: la nuova fonte di vantaggio competitivo, in Ghemawat P. e altri, Strategie. Il vantaggio competitivo secondo i maestri della Harvard Business School, Il Sole 24 Ore Libri, Milan, 2003.

Stalk G. Jr., Time - The Next Source Of Competitive Advantage, Harvard Business Review, Volume 66, n. 4, 1988.

Stalk G. Jr., Hout T.M., Competing Against Time: How Time-based Competition Is Reshaping Global Markets, Free Press, New York, 1990.

\section{Notes}

1 Cf. S. M. Brondoni, Ouverture de 'Global Markets \& Marketing Research', Symphonya. Emerging Issues in Management (symphonya.unimib.it), n. 1, 2003.

${ }^{2}$ P. de Woot states that 'companies are among the few organisations that have succeeded in simultaneously crossing all the thresholds of globalisation: the size threshold, many of them are "multinationals" and they cross the frontiers of Nation-States, the time threshold, companies adopt longterm strategies using measures that are not comparable to those of the political, administrative or educational world; the threshold of complexity, they become capable of effectively managing differences, multiple rationality, risk, and the development of resources, which enables them to change and adapt rapidly; the threshold of information and communication, which allows them to be in direct contact with the world and to act effectively and promptly', see P. de Woot, The Challenges of Economic Globalisation. Business, Competition and Society, Symphonya. Emerging Issues in Management (symphonya.unimib.it), n. 2, 2002.

${ }^{3}$ Cf. H. I. Ansoff, La strategia d'impresa, Franco Angeli, Milan, 1974; A P. Jr. Sloan, La mia General Motors, Il Sole 24 Ore Libri, Milan, 1991.

${ }^{4}$ In modular production, suppliers of preassembled modules adopt an efficiency fanatic's concept of time: 'because they are responsible for delivering the module, more often than not (this concept) is based on synchronic just-in-time delivery... suppliers of pre-assembled modules also guarantee to the client company both the necessary technical assistance and rapid, efficient changes and adaptation of manufacturing output and processes...' See E. Massaroni, 'Forme, caratteri e divenire sistemico dei rapporti di fornitura' in G. M. Golinelli, L'approccio sistemico al governo dell'impresa. Valorizzazione delle capacità, rapporti intersistemici e rischio nell'azione di governo, Volume III, CEDAM, Padua, 2002.

${ }^{5}$ According to Guatri, the constant action of three elements of the New Economy (high growth rates, extraordinarily high competition and a great capacity to attract capital) all combine to impose rapid change on the competitive context which determines the emergence of a new economic dimension to managerial decision-making: time. 'Time becomes important, not only in the financial sense but also in the strategic-economic sense, in the perspective of momentum, in other words of 
the capacity to grasp opportunities immediately ... In the end, the superiority of the business model is linked to certain attitudes of the organisation (flexibility, interaction, etc.) which define its ability to grasp the momentum, i.e. to adapt to environmental discontinuity. This ability underpins the mechanism of self-reinforcement (which has been called the 'gorilla game') of successful businesses, which manage to implement prestigious resources, to generate new opportunities, to maintain high the level of customer loyalty, etc., thanks to high rates of innovation, circumstances which translate into both higher growth rates and an ever-stronger competitive advantage (longer lasting)...' see L. Guatri, Freedomland. Un'esperienza sul valore conseguente a uno start-up IPO, EGEA, Milan, 2002.

${ }^{6}$ Cf. J.J. Lambin, S.M. Brondoni Ouverture de 'Market-Driven Management', Symphonya. Emerging Issues in Management (symphonya.unimib.it), n. 2, 2000.

${ }^{7}$ R. Normann identifies in the conceptualisation of time an important structural dimension of the process of restructuring a business, obtained by reinterpreting the time dimension in an extremely dynamic context. We go from a traditional vision of time, focused in the perennial rebirth of the present and a continuous shifting of that present, to an alternative vision of the relationship with time, the 'here and now', made of projections into the future of experience gained in the past in order to enrich the present. Cf. R. Normann, Ridisegnare l'impresa, ETAS Libri, Milan, 2002. If a student of strategy considers from a managerial perspective what Swedish novelist Christina Claesson had to say about time in 1994 ('time never passes. It arrives, arrives, arrive'), he will suggest a new interpretation of the individual's relationship with time: no longer from left to right, but 'simultaneously moving the past and images of the future into the present'. See C. Claesson, Mental Overlevnadsteknik, Carlssons Bokforlag, Stockholm, 1994.

${ }^{8}$ Cf. P. Askenazy, D. Thesmar, M. Thoenig, Time Based Competition and Innovation, ENSAE, New York, 2003.

9 see S.M. Brondoni, A. Giulivi, Competizione time-based e nuova progettualità della comunicazione aziendale, Sinergie, n. 9, 1993.

10 'It is possible to find 'feedback', or 'feed-forward' retroaction, often also combined in relation to the critical state of the variables under examination and their economic significance... the benchmark time horizon is obviously linked to the type of variable being considered and the possible related reproposition. The activities being analysed also become important, as well as their related impact on corporate economic dynamics.' See D.M. Salvioni, Il sistema di controllo della gestione, Giappichelli Editore, Turin, 1997.

${ }^{11}$ See F. Amigoni (ed.), Sistemi di controllo e misurazione delle performance, Egea, Milan, 2001.

12 'The Boston Retail manager can use the feedback regarding the excellent performance of a contract, to understand how other contracts can perform better; the supervisor responsible for a shift on the assembly line can discuss the information regarding manufacturing deficiencies with the foremen to understand what measures can be adopted to solve the problem; the head of the division can decide to cut maintenance expenditure to try to meet profit targets.' See F. Amigoni, 2004, op. cit.

13 Cf. L. Cusella, 'Feedback, motivation and performance' in Handbook of organizational communication (various authors), Sage, Beverly Hills, 1987.

14 'Even products register profound innovations, with clear and marked reflections on the competitive elements of corporate communications... an initial innovative dimension can be found in the design simplifications that... characterise the new product. This trend can be attributed to a reduction in the useful life of the products themselves and a corresponding increase in disposable products... we must also underline the growing spread of knowledge about new products.' See S.M. Brondoni, 'Comunicazione integrata d'impresa e 'nuove sfide' competitive', in R. Filippini, G. Pagliarani, G. Petroni (ed.), 'Progettare e gestire l'impresa innovativa. I nuovi percorsi per affrontare la complessità degli anni Novanta', ETAS Libri, Milan, 1992.

15 'Global networks that operate in enlarged competition spaces (enhancing and exploiting the intangible assets of brand equity, information system and corporate culture) obtain extremely extensive, 
sophisticated information about the market.' See J.J. Lambin Ouverture de 'Market-Space Management', Symphonya. Emerging Issues in Management (symphonya.unimib.it), n. 1, 2002.

16 'Additional new competitive challenges, which have a specific influence on the problems of corporate communication, can be identified in the dynamics of spatial-temporal competition. In this regard, one important evolutionary factor can be found in the loss of significance ... of the competitive reference to a close domain, which typically coincides with peculiar national contexts. In particular, the reference to the physical competition space now appears primitive and in any case limited in relation to a concept of competition in which specific geographical contexts are functionally required to temporarily express peculiar partial competitive advantages (i.e. regarding output, marketing, research and development, etc.) to be coordinated on vast scales of operation. ... We can also note that competitive action and reaction times have been reduced... Recently this orientation has been reinforced in particular by an increase in electronic information flows; these flows make it possible to dialogue... with numerous targets (active competitive parties)... to develop constantly monitored competitive actions, but at the same time make it possible to develop competitive intervention plans based on constantly updated information.' See S. M. Brondoni, 1992, cit.

17 'In terms of time, market-space management also affects the temporal efficiency of manufacturing and the supply chain of specific goods; networks located in various places replace sequential output and processes, with the result that manufacturing/delivery time represents the sum of the production and logistic needs of the operating units that make up the network.' See J. J. Lambin, 2002, cit.

${ }^{18}$ Cf. F. Gnecchi, Le private label nell'economia d'impresa, Giappichelli Editore, Turin, 2002.

${ }^{19}$ Source: www.tesco.com.

${ }^{20}$ Competitive intensity is defined as 'the degree of interdependence between competitors and regards the importance that the operations of one competitor have for the other competitors. The greater the significance for one company of information about the operations of its competitors, the greater the competitive intensity of that market.' See M. Corniani, Demand Bubble Management, Symphonya. Emerging Issues in Management (symphonya.unimib.it), n. 1, 2002.

${ }^{21}$ Cf. E. Rullani, Produzione snella e post-fordismo: alla ricerca di un paradigma emergente, Economia e Politica Industriale, n. 84, 1994.

${ }^{22}$ See G. Panati and M. G. Golinelli, Tecnica economica industriale e commerciale. Imprese, strategia e management, Volume I-II, La Nuova Italia Scientifica, Rome, 1991.

${ }^{23}$ Cf. J.J. Lambin, S.M. Brondoni, 2000, cit.

'The large car-makers must face a devastating new phenomenon of 'over-supply', which is radically rewriting the rules of the game. Business is highly profitable only for those who know how to intercept demand trends and to create new consumption niches (bubble making), being the first to satisfy them (time-to-market) and achieving a good profit by abandoning the bubble in time (time competition), when imitator competitors arrive. In concrete terms, the choice of the moment to enter and exit is typical of marketing policy in conditions of over-supply, which demands at least strict programming of brand/product personality management costs.' See S.M. Brondoni, Le due regole del mercato. Vince per primo chi capisce le esigenze dei consumatori, Il Sole 24 Ore, May 3, 1999.

${ }^{24}$ See M. Corniani, 2002, cit.

${ }^{25}$ Martinelli states that demand bubbles 'take advantage of two variables: the 'creative supply' variable and the 'time' variable, which is the main ally of the bubble... The time variable comes into play in a context because there is a beginning and an end, as well as a rhythmical sequence of 'nonseasonal fruit and vegetable'.' See A.F. Martinelli, From Cornering to Virtual Cornering, Symphonya. Emerging Issues in Management (symphonya.unimib.it), n. 1, 2002.

${ }^{26}$ Corniani also states that ' $\ldots$ while the imperative of time compression demands that execution time be reduced, and time value identifies the best moment to act among a variety of possible moments, time duration makes it necessary to plan the duration of an action, in other words to quantify a time interval in which a phenomenon is allowed to develop so that the effects obtained can meet expectations in the best possible way.' See M. Corniani, 2002, cit. 
27 See S. Hum, H. Sim, Time-Based Competition: Literature Review And Implications For Modelling, International Journal of Operations and Production Management, Volume 16, Issue 1, 1996.

${ }^{28}$ Cf. S.M. Brondoni, 2003., cit..

29 See H.T. Johnson, Relevance Regained. From Top-Down Control To Bottom-Up Empowerment, The Free Press, New York, 1992.

${ }^{30}$ This refers to mathematical models to determine the size of safety stock, minimum permanent operating inventories, actual inventories, and the average inventory level for given periods of time. Cf. G. Pivato, Le scorte d'esercizio nelle imprese industriali e mercantili, Cavalleri, Como, 1942; P. Onida, Economia d'azienda, Utet, Turin, 1970; P. Onida, La logica e il sistema delle rilevazioni quantitative d'azienda, Giuffrè, Milan, 1970.

${ }^{31}$ See P. Onida, Natura e limiti della politica di bilancio, Rivista dei Dottori Commercialisti, November-December 1974.

${ }^{32}$ Cf. J. J. Lambin, Marketing strategico e operativo, Mc Graw Hill, Milan, 2004. 